Discourse and Communication for Sustainable Education, vol. 7, no. 2, pp. 68-91, 2016

\title{
Envisioning Complexity: Towards a New Conceptualization of Educational Research for Sustainability
}

\author{
Anita Pipere \\ Daugavpils University, Latvia
}

\begin{abstract}
This paper aims to present some conceptual insights into the research paradigm of complexity that deals with such problems like sustainability, education, and, more specifically sustainability education. The transdisciplinary perspective and cognitive approaches of a hermeneutical cycle and semantic waves used in argumentation assist in grasping the essence of complexity and the main principles of complex dynamic systems. The comparison of simple, complicated and complex systems in a field of sustainability education provides an example of using complexity thinking with social systems. Then the complexity in an epistemological context, as the research paradigm, could be used for dealing with the challenging problems of sustainability, education and sustainability education from the point of view of post-normal science. The concept of transdisciplinarity has been developed as a research framework starting from the general approaches to its application for sustainability, education and sustainability education. The specific types of collaboration in educational research for sustainability and the modes of knowledge produced by transdisciplinary research in this field will be described, ending with reflections and suggestions for further analysis.
\end{abstract}

Keywords: complexity, sustainability, educational research, sustainability education, transdisciplinarity.

\section{Introduction}

The recently emerged idea of viewing sustainability and related issues within the discourse of complexity has been examined in different contexts and appears to be the promising course of action in terms of transforming the research in these fields (Camaren \& Swilling, 2014; Espinosa \& Walker, 2011; Guillaume, 2014; Harris, 2007; Norberg \& Cumming, 2008; Swilling \& Annecke, 2011; Tainter, 2006; Valentinov, 2014; Wells, 2013, etc.). The author's analysis aims to stimulate feedback and creative collective reflections on this new approach to inquiry that is ultimately oriented toward more sustainable existence, relationships and meaning making. This paper profers some conceptual insights into the research paradigm of complexity to deal with such life-world problems like sustainability, education, and, more specifically - sustainability education. 
At the outset it is worth reminding one that every theory, in order to be useful, relevant and entitled for further development, should be grounded on properly defined concepts that are described both using flexible approaches and attitudes of comprehensiveness and penetration (Knight, 2008). Especially, the research on sustainability, since its inception, has already been criticized for the lack of conceptual clarity and precision. Education per se and sustainability education have been recognized for having several biases and ambiguous research objects as well as an incapacity to deal with the most intractable problems of public education (see more in Fleener, 2016; Pipere, Veisson, \& Salite, 2015). On the one hand, this can be interpreted as assuming that sustainability and related problems can be grasped and dealt with only using the complexity paradigm that asks for more intricate and comprehensive views and is not easily simplified and described (Wells, 2013). By trying to explain and model complex phenomena in a uniform and exact way, we loose their complex nature. On the other hand, these efforts could have failed because during the previous decades scholars from different disciplines and contexts frequently attempted to define the concepts according to their compartmental understanding and approach, that, in the majority, was based on classical positivist/ post-positivist paradigm and expressed via normative, standartized, "top-down" or even purely ideological discourse. These rarely looked for joint research, common and unified knowledge or collaborative implementation of the results with the practitioners in the field.

This paper is conceived as an attempt at conceptual analysis, allowing for more flexibility and less rigour than theoretical analysis while involving speculations about connections that have to be elaborated and confirmed in empirical studies. The relations between certain concepts and the necessary and sufficient conditions of the application of given concepts will be demonstrated in brief (Bunnin \& Yu, 2004). The structure of the paper bears the features of a spiral approach to knowledge (Bruner, 1960) and qualities of the hermeneutical circle (Mantzavinos, 2016), while the content-related aspects will be elaborated from the transdisciplinary perspective integrating the discourses from the philosophy of science, educational sciences, psychology, sustainability science, etc.

In respect to Sartori's classic rules of concept formation and his so-called ladder of abstraction (Sartori, 1984), the low, medium and high levels of abstraction are related to the range of covered cases - the more abstract the concept is, the wider the range of cases. In this paper the sustainability and related issues are conceived from the highest degree of abstraction that allows one to have 'a bird's-eye view' and coverage of wide range of cases, situations and contexts. Also, some semantic waves (Maton, 2014) will be employed as to strengthen and weaken context dependence and to concentrate on the meaning as it is more natural for the scientific discourse of social sciences and education to bring forth specific examples from real life. Concept of complexity allows us to climb up and reach the higher level of abstraction than the narrow concepts used in different academic disciplines to explain sustainability, education and sustainable education. In this paper the conceptual analysis will be applied not only to the content of these issues, but also to the research paradigm that is used in exploration of these matters.

In order to improve the comprehension of sustainability as well as to understand and conquer unsustainability, both natural and social sciences as well as humanities need to detail not only the novel world outlook and interpretation of the world, but also the brand-new approaches to the solution of local and global issues. The comprehension of these issues within a scope of the old paradigms apparently was not consistent 
with the multidimensional and transdisciplinary nature of these issues. This situation imminently leads to some ethical dilemma, which is especially relevant in contemporary social and educational sciences. What would be more important for the humanity: 1) to strive toward logicaly grounded, explicit, objective, namely, "scientific" view of the world, that reflects important relationships between the single elements of individual and systems of social mileu in any specific scientific discipline, so as to vindicate the traditional particularity of science as some elitist field or 2) to emphasize the utilitarian (not egoistic) or instrumental aspect of science, focusing on urgent individual and social issues and aiming for creative involvement of all possible resources (both in terms of scientific and other forms of comprehending the world) as to reduce the present and potential issues of individual, society and the Earth (Pipere, 2016)? This paper aims to review and discuss some theoretical ideas that essentially could help researchers in dealing with such dilemmas now and in the future.

The main part of the paper consists of two chapters aiming to define the complexity and suggesting the application of its' principles to the research of intertwined problems. The both chapters are significant for the presentation since the audience of educational researchers and practitioners might still have rather fragmented perspective on the phenomena of complexity introduced in scientific discourse only for the last two decades (Heilighen, 2008). So, as to provide the outlook of complexity based research paradigm regarding sustainability, education and sustainability education, the author will start with the definitions of complexity and the main principles of complex dynamic systems. Than, the deeper implications of complexity for the research in a field of sustainability, education and sustainability education will be provided based on the concepts of postnormal science, wicked problems, transdisciplinarity, etc. The paper will end with some reflections, conclusions and suggestions for the further analysis.

\section{Complexity and Main Principles of Complex Dynamic Systems}

Let's start with the challenge of complexity definition, followed by sets of selected complexity principles and illustration of difference between simple, complicated and complex systems. To make this discourse more relevant to sustainability and education as the main areas of interest for the journal audience, the examples of complexity principles and systems will be borrowed both from the general field of education and sustainability education.

\section{Comprehending Complexity}

Currently the term of complexity has been interpreted very differently and used in growing number of studies related to various disciplines in both the US and Europe (Dann \& Barclay, 2006). In a general way complexity usually has been defined using some principles of composition (structure) or existence (functioning) of complex systems. For instance, the science of complexity can be defined as a science exploring the phenomena emerging in a totality of interacting objects or as "the dynamic interactions of multiple elements engaged in self-organizing processes" (Wells, 2013, p. 35) Example of complexity is a crowd, as it is a phenomenon emerging in interacting body of human beings (Johnson, 2009). Other scientists (e.g., Gershenson, 2013) acknowledge that it is hard to separate the elements of complex system since they are interdepent and exist in 
respective interaction. Many scholars admit that the exact definition of complexity is impossible (Heilighen, 2008; Wells, 2013), it only can be placed in between the order and chaos. The theory of complexity has grown from and still builds on the systems theory and chaos theory, striving to demonstrate, why the whole is larger than the sum of its' parts and how the components of the whole merge and interact in order to create higher level models through the systems' learning, evolution and adaptation.

To date, the complexity vision has been promoted largely in a very piecemeal fashion, with each theorist mentioning a few of the core principles and focusing on one or two of the major frameworks within complex theories (Wells, 2013). In her book "Complexity and sustainability" Wells (2013) suggests a set of six complex dynamic systems principles: nonlinearity, feedback, networks, hierarchy, emergence and self-organization that could be found both in natural and social systems. Than she elaborates two sets of 50 principles each applicable for sustainability studies and explicitly related to sustainability. Before advancing with further analysis, we need to consider short definitions of the six foundational principles mentioned above, based on the suggestions from Wells (2013) and other authors:

1) Nonlinearity is a principle behind chaos theory designating the disproportionality between causes and effects and showing that small initial changes can lead to large outcomes.

2) Feedback can be explained as a process of circular causality by which the output of the system is fed back to the input.

3) Networks are dynamical systems consisting of nodes with links of interactions between them.

4) Hierarchy refers to the interrelated nested systems where each of the subsystems is subordinated to the system to which it belongs.

5) Emergence is "a process by which relatively simple rules lead to complex pattern formation" (Holland, 1998, p. 3).

6) Self-organization can be viewed as the central feature of life and "spontaneous emergence of global structure out of local interactions” (Heilighen, 2008, p. 6).

However, in assistance of researchers and practitioners in sustainability and related issues, a more extensive set of complex dynamic system features could be created using the principles proposed and defined by several authors (Checkland, 1991; Garnett, 1997; Johnson, 2009; Holman, 2010; Von Bertalanffy, 1968). Table 1 includes 10 qualities of complex systems with short descriptions and illustrations. In this table these qualities are related to socio-cultural systems and presented starting from the structure and components of the system, than moving to the behaviour and development of system and concluding with the context from which to approach the system. Two illustrative examples from the field of education in terms of class of pupils at school and system of teacher's beliefs could serve as an introductory thinking exercise using semantic waves (transition from more abstract to more specific meaning) to prepare for more intricate relationships between complexity and sustainability issues. These two examples are obvious manifestations of two important aspects of education as social system (Fleener, 2016), namely, social interaction (class at school) and meaning making (teacher's beliefs). Accordingly, in the example of class the individual pupils could be perceived as the elements or agents of the system, while in the system of teachers' beliefs, individual beliefs can behave as elements or agents connected within a holistic system of teacher's beliefs. 
Table 1

Main Principles of Complex Dynamic Systems

\begin{tabular}{|c|c|c|c|}
\hline Principle & Description & Example: class at school & $\begin{array}{c}\text { Example: system of } \\
\text { teacher's beliefs }\end{array}$ \\
\hline Holism & $\begin{array}{l}\text { The system is an integrated } \\
\text { whole and its' features } \\
\text { cannot be reduced to the } \\
\text { sum of elements of this } \\
\text { system. }\end{array}$ & $\begin{array}{l}\text { Class as an integrated } \\
\text { whole cannot be reduced } \\
\text { to the simple sum of } \\
\text { individual students and } \\
\text { have some integral } \\
\text { features appearing due to } \\
\text { interaction of pupils on } \\
\text { different levels. }\end{array}$ & $\begin{array}{l}\text { System of beliefs is an } \\
\text { integrated and unique } \\
\text { wholeness, though con- } \\
\text { sisting of numerous } \\
\text { beliefs, feeding the prac- } \\
\text { tice of every individual } \\
\text { teacher. }\end{array}$ \\
\hline Hierarchy & $\begin{array}{l}\text { Every system contains the } \\
\text { set of many interacting, } \\
\text { similar but at the same } \\
\text { time independent agents/ } \\
\text { elements. These agents } \\
\text { sustain the subsystems that } \\
\text { can be merged into larger } \\
\text { systems, therefore creating } \\
\text { the hierarchy of systems } \\
\text { (e.g., nested structure). }\end{array}$ & $\begin{array}{l}\text { Hierarchy of pupils in } \\
\text { class in terms of their } \\
\text { academic performance, } \\
\text { e.g., considering the } \\
\text { number of disciplines } \\
\text { with good/average/poor } \\
\text { academic achievement. }\end{array}$ & $\begin{array}{l}\text { The belief system can } \\
\text { sustain the several sets of } \\
\text { nested beliefs, starting } \\
\text { from general philosophi- } \\
\text { cal beliefs related to the } \\
\text { aims of education to the } \\
\text { very specific beliefs, e.g., } \\
\text { about proper non-verbal } \\
\text { behavior communicating } \\
\text { with pupils' parents. }\end{array}$ \\
\hline Rules & $\begin{array}{l}\text { Each agent/element } \\
\text { accepts the local common } \\
\text { rules of the system. }\end{array}$ & $\begin{array}{l}\text { Every pupil should accept } \\
\text { the common rules of } \\
\text { conduct set within the } \\
\text { class. }\end{array}$ & $\begin{array}{l}\text { All beliefs within the } \\
\text { belief system are sub- } \\
\text { jected to the same rules } \\
\text { of occurence, develop- } \\
\text { ment, transformation, } \\
\text { ageing and suspension. }\end{array}$ \\
\hline Feedback & $\begin{array}{l}\text { The behaviour of system's } \\
\text { agents/elements is deter- } \\
\text { mined by memory or feed- } \\
\text { back that can be both } \\
\text { positive (increasing the } \\
\text { benefits of the system) } \\
\text { and negative (destroying } \\
\text { the system) (e.g., non- } \\
\text { linear behaviour of system). }\end{array}$ & $\begin{array}{l}\text { The class provides feed- } \\
\text { back to external influence, } \\
\text { e.g. in form of improved } \\
\text { academic achievements } \\
\text { responding to more } \\
\text { appropriate teaching } \\
\text { methods. }\end{array}$ & $\begin{array}{l}\text { The teacher's beliefs are } \\
\text { tested in teaching practice } \\
\text { and the further destiny of } \\
\text { each belief depends from } \\
\text { the feedback in form of } \\
\text { students' performance } \\
\text { outcomes. }\end{array}$ \\
\hline Adaptation & $\begin{array}{l}\text { To survive, the agents/ } \\
\text { elements have to adapt } \\
\text { their behaviour to the } \\
\text { new situation according } \\
\text { to their experience } \\
\text { (history). }\end{array}$ & $\begin{array}{l}\text { Pupils in class adapt } \\
\text { their behaviour to the } \\
\text { new curricular demands } \\
\text { in line with their pre- } \\
\text { vious learning experience. }\end{array}$ & $\begin{array}{l}\text { The novice teacher's } \\
\text { beliefs about the most } \\
\text { effective teaching } \\
\text { methods can be modified } \\
\text { starting his/her teaching } \\
\text { practice at school. }\end{array}$ \\
\hline Openness & $\begin{array}{l}\text { Usually such systems are } \\
\text { open systems that behave } \\
\text { like living organisms. }\end{array}$ & $\begin{array}{l}\text { Class at school can be } \\
\text { viewed as a living orga- } \\
\text { nism that learns, adapts } \\
\text { to external influences } \\
\text { and engage in evolutio- } \\
\text { nary processes (e.g., } \\
\text { stages of group dynamics). }\end{array}$ & $\begin{array}{l}\text { The system of teacher's } \\
\text { beliefs is open to constant } \\
\text { re-evaluation, changes } \\
\text { and development, e.g., } \\
\text { out-dated beliefs are } \\
\text { replaced by new more } \\
\text { adequate beliefs. }\end{array}$ \\
\hline
\end{tabular}


Sequel to Table 1.

\begin{tabular}{|c|c|c|c|}
\hline Emergence & $\begin{array}{l}\text { Higher-order complexity } \\
\text { arising out of chaos in } \\
\text { which novel, coherent } \\
\text { structures coalesce } \\
\text { through interactions } \\
\text { among the diverse entities } \\
\text { of a system. These phe- } \\
\text { nomena usually appear } \\
\text { naturally with no help } \\
\text { from some "invisible } \\
\text { hand" or central manage- } \\
\text { ment. }\end{array}$ & $\begin{array}{l}\text { Even in a class of very } \\
\text { low ability pupils the } \\
\text { high achievements in } \\
\text { certain topics can emerge } \\
\text { without any specific } \\
\text { impact from teacher. }\end{array}$ & $\begin{array}{l}\text { In a system of beliefs, } \\
\text { new complex beliefs can } \\
\text { emerge unexpectedly, } \\
\text { integrating several } \\
\text { simpler beliefs. }\end{array}$ \\
\hline $\begin{array}{l}\text { Self- } \\
\text { organization }\end{array}$ & $\begin{array}{l}\text { The system demonstrates } \\
\text { the intricated } \\
\text { combination of orderly } \\
\text { and chaotic behaviour. }\end{array}$ & $\begin{array}{l}\text { The same class of pupils } \\
\text { can show the orderly } \\
\text { behaviour during the } \\
\text { high stake examination } \\
\text { and very chaotic } \\
\text { behaviour during the } \\
\text { break after the test. }\end{array}$ & $\begin{array}{l}\text { Initially chaotic set of } \\
\text { beliefs obtained during } \\
\text { the teacher training can } \\
\text { be restructured and } \\
\text { shaped into more orderly } \\
\text { structures and deliberate } \\
\text { interrelationships with } \\
\text { the gradual evolvement } \\
\text { of teaching practice. }\end{array}$ \\
\hline $\begin{array}{l}\text { Complexi- } \\
\text { fication }\end{array}$ & $\begin{array}{l}\text { The system shows the } \\
\text { progress of complexity, } \\
\text { e.g., with time the system } \\
\text { becomes larger and more } \\
\text { complex (increases the } \\
\text { number of elements and } \\
\text { interactions). }\end{array}$ & $\begin{array}{l}\text { Learning together (e.g., } \\
\text { from grade one to grade } \\
\text { nine), pupils gradually } \\
\text { establish growing number } \\
\text { of interactions between } \\
\text { their cognitive, affective } \\
\text { and behavioural patterns. }\end{array}$ & $\begin{array}{l}\text { Growing experience of } \\
\text { teacher determines the } \\
\text { growing limits of } \\
\text { teacher's belief system: } \\
\text { the number of single } \\
\text { beliefs and interactions } \\
\text { between them. }\end{array}$ \\
\hline Observer & $\begin{array}{l}\text { The boundaries of system } \\
\text { or, in other words, what } \\
\text { are included in or } \\
\text { excluded from the } \\
\text { system, is determined by } \\
\text { the observer. }\end{array}$ & $\begin{array}{l}\text { Comparing class teacher, } \\
\text { school principal and } \\
\text { school inspector as the } \\
\text { observers of class, each } \\
\text { of them will see different } \\
\text { elements and aspects to } \\
\text { be included or excluded } \\
\text { in the given class as a } \\
\text { system. }\end{array}$ & $\begin{array}{l}\text { From the point of view of } \\
\text { pupils' parents, the } \\
\text { teacher's system of beliefs } \\
\text { should include the } \\
\text { specific subsystem of } \\
\text { beliefs regarding their } \\
\text { offspring. }\end{array}$ \\
\hline
\end{tabular}

In fact, both the definitions of principles and their examples should be viewed as ultimate simplification, since, as it was mentioned before, complex systems can not be grasped with strict, simple and unambiguos language and they are inherently multidimensional. Suggested examples should be viewed just as one from the numerous alternatives of possible interpretations in relation to the principles of complex dynamic system. The system of teacher's beliefs as a complex system has been described also in several other papers (e.g., Šapkova, 2014; Zheng, 2015), while classrooms as complex adaptive systems already were elaborated mostly in language learning context (see Burns \& Knox, 2011; Logan \& Schumann, 2005; Newell, 2008; Young, 2016). 


\section{Simple, Complicated and Complex Systems}

Many authors, describing complexity, stress the neccesity to distinguish between complicated and complex systems. Though, trying to grasp the growing complexity of the systems, the nature of the systems can be better demonstrated ordering them on the range from simple to complex systems. Adapted from the original table by Glouberman and Zimmerman (2002) to the specific content in connection to sustainability and education, Table 2 shows three types of problems related to sustainability education that can be treated as simple, complicated and complex systems.

Table 2

Simple, Complicated and Complex Systems (adapted and modified from Glouberman \& Zimmerman, 2002, p. 2)

\begin{tabular}{lll}
\hline Simple problem & Complicated problem & Complex problem \\
$\begin{array}{l}\text { Delivering a lesson using } \\
\text { teaching tools and materials } \\
\text { for ESD }\end{array}$ & $\begin{array}{l}\text { Integrating sustainability into } \\
\text { all academic programs of } \\
\text { certain university }\end{array}$ & $\begin{array}{l}\text { Educating youth oriented } \\
\text { toward sustainability values }\end{array}$ \\
\hline $\begin{array}{l}\text { Strict following of the } \\
\text { teaching materials is } \\
\text { essential }\end{array}$ & $\begin{array}{l}\text { Guidelines are critical and } \\
\text { necessary }\end{array}$ & $\begin{array}{l}\text { Guidelines and teaching } \\
\text { materials have a limited } \\
\text { application }\end{array}$ \\
\hline $\begin{array}{l}\text { Some activities from the } \\
\text { teaching materials can be } \\
\text { pre-tested in different }\end{array}$ & $\begin{array}{l}\text { Successful introduction of sus- } \\
\text { tainability in one academic } \\
\text { learning situations }\end{array}$ & $\begin{array}{l}\text { Educating one person or even } \\
\text { one class of pupils/group of }\end{array}$ \\
$\begin{array}{ll}\text { program increases assurance } \\
\text { that the introduction in other } \\
\text { programms also will be }\end{array}$ & $\begin{array}{l}\text { but no assurance of success } \\
\text { with the next }\end{array}$ \\
$\begin{array}{l}\text { No particular expertise in } \\
\text { ESD is needed, but pedago- } \\
\text { gical expertise of teacher } \\
\text { increases success rate }\end{array}$ & $\begin{array}{l}\text { High level of expertise in a } \\
\text { variety of fields as well as the } \\
\text { teamwork are necessary for } \\
\text { success }\end{array}$ & $\begin{array}{l}\text { Expertise (in sustainability } \\
\text { and/or education) can contri- } \\
\text { bute but is neither necessary } \\
\text { nor sufficient to assure success }\end{array}$ \\
\hline $\begin{array}{l}\text { Application of same mate- } \\
\text { rials by same teacher in same } \\
\text { class usually will determine } \\
\text { similar learning outcomes }\end{array}$ & $\begin{array}{l}\text { The structure of different uni- } \\
\text { versities and academic prog- } \\
\text { ramms in one specific univer- } \\
\text { sity are similar in many ways }\end{array}$ & $\begin{array}{l}\text { Every case is unique and must } \\
\text { be understood as individual } \\
\text { and extraordinary }\end{array}$ \\
$\begin{array}{l}\text { The best approbated activi- } \\
\text { ties from the teaching mate- } \\
\text { rials give good results most } \\
\text { of the time }\end{array}$ & $\begin{array}{l}\text { There is a high degree of } \\
\text { certainty of outcome }\end{array}$ & $\begin{array}{l}\text { Uncertainty of outcome } \\
\text { remains }\end{array}$ \\
$\begin{array}{l}\text { Optimistic approach to } \\
\text { problem possible }\end{array}$ & $\begin{array}{l}\text { Optimistic approach to } \\
\text { problem possible }\end{array}$ & $\begin{array}{l}\text { Optimistic approach to } \\
\text { problem possible }\end{array}$ \\
\hline
\end{tabular}

As seen in Table 2, simple problems in a field of education like delivering lesson using ready-made ESD teaching materials can comprise significant issues of educational technology or terminology, but as soon as these issues are mastered, there is a large possibility, that following teaching materials will ensure success. The nature of complicated problems frequently is linked not only to the extent of the problem, but also to larger requirements regarding the expertise and coordination of different branches related to given issue. Since the study programms in a framework of one university usually are more or less similar (at least in terms of structure and curricular approach), also in this 
case we can be rather sure about the possibility to repeat the successful integration of sustainability principles in several programs. In contrast, complex systems are essentially based on relationships and, among others, such features of relationships as self-organisation, interaction and evolution. Complex systems cannot be grasped as simple or complicated systems, using evidence, politics, planning and management. Treating the issue of educating youth toward sustainability values as a complex system and analysing its peculiarities, one can conclude that the most useful solutions usually emerge in a dialogue, discussions, interaction and networking between all stakeholders involved in education, self-organization of hierarchical systems participating in value education, etc.

Besides, complexity is not an inherent material property or substance of some kind; rather it is relevant relative to systems, interactions, observers, and particular inquiries (Wells, 2013). Depending on the relationships of the observer to the system and the nature of the inquiry, what one see as simple in one moment, can be perceived as complex the next. Returning to the Table 1, puting the observer inside the all three problems/ systems (in classroom, university, community/society), it appears that actually every mentioned problem can be also viewed as a complex problem, at least in a way that delivering any lesson implies learning that can be grasped as a complex problem, while introducing novel guiding principles in organization (i.e., university) is obviously related to certain networking, hierarchy and self-organization. Ultimately, in terms of complexity as a paradigm, it undergirds all endeavours connected with human being and society, besides, in these systems the complexity is more evident than in any physical or biological system.

It is interesting that, in accordance with Poli, the distinctive and extraordinary features of complex systems are related to their creative nature: "Being creative includes the capacity to change, learn, and over time become different from what one was before. But it is more than this. Everything changes, but not everything is creative. To mention but one component of creativity, the capacity to (either implicitly or explicitly) reframe is one of the defining features of creativity. Creativity also includes some capacity to see values and disvalues, and to accept and reject them. Therefore, it is also the source of hope and despair. None of these properties are possessed by complicated systems" (Poli, 2013, p.145).

\section{Complexity as a Research Paradigm for Wicked Problems}

According to Wells (2013), complexity operates in physical, biological and social systems. In its turn, education is also a significant social system determining the vitality of any society (Fleener, 2016).

Presently the increasing number authors explore the links between complexity and education (e.g., Davis \& Sumara, 2006, 2008; Doll, Fleener, Trueit, \& Julien, 2006; Mason, 2008; Osberg \& Biesta, 2010, etc.), however, the deep and systematical analysis of the whole array of complexity principles as well as the empirical verification of these principles in a broad field of education not to mention ESD is still ahead. The next part of the paper will focus on the complexity in epistemological context, as the research paradigm that could be used dealing with the demanding problems - issues in sustainability, education and sustainability education. 


\section{Complexity as a Research Paradigm for Sustainability}

As it has already become clear, complexity is not just a phenomenon or a set of phenomena, not even a method, but rather an epistemological paradigm, an approach to inquiry and practice. Wells (2013) suggests using the term "complex thinking" that means applying the set of ideas, principles, models to investigate the properties of any systems. Sustainability and related issues represent the highly complex situation and subjects that ask for the conceptualization of new research paradigm. Such conceptualization might be possible introducing post-normal science (Riccucci, 2008). The term 'post-normal' science, introduced by Jerome Ravetz, designates the management of complex science-related issues focusing on previously neglected aspects like uncertainty, value loading and a plurality of legitimate perspectives. The phenomena of environment and society cannot be grasped or managed as simple systems, these phenomena will always present anomalies and surprises. Although the principles of post-normal science has been developed, redeveloped and even strongly criticized, the main assumtions still can be stated as 1) the scientific management of uncertainty and of quality, 2) the multiplicity of perspectives and commitments, and 3) the intellectual and social structures that reflect problem-solving activities (Funtowicz \& Ravetz, 1993). Post-normal science is looking for the answers on questions "What-about?" and "What-if?" and deals with high risks, uncertainty and divergent values, situations where objectivity is not always achievable. Another very important feature of post-normal science, highly relevant to this paper, is a new method for creation of scientific knowledge - an extended peer community. In such community a dialogue is created among all stakeholders, regardless of their position or qualification (Riccucci, 2008).

Another concept, interrelated with sustainability, post-normal science and inquiry in complex systems, is the concept of wicked problems - challenging problems because of their complexity that usually do not yield to the simple solutions. Many authors have recognized that complexity is a tool to deal with such a wicked problem like sustainability. Authors like Wells (2013), Peterson (2014), Conklin, (2005), Valentinov (2014) summarize the description of wicked problems by the following four criteria: 1) no definitive formulation of the problem exists, 2) its solution is not true or false, but rather better or worse, 3 ) stakeholders have radically different frames of reference concerning the problem, 4) the underlying cause and effect relationships related to the problem are complex, systemic and either unknown or highly uncertain. Wicked problems are not solvable, just manageable (Peterson, 2014). If the wicked problems can be explicitly correlated with the features of complex problems (in Table 2 - complex problem of value orientation for youth), when in tame problems (e.g., algebraic equation with unknown values) traditional linear approach is enough (in Table 2 - simple problem of delivering lesson using teaching materials - it has a clear problem statement, we know when the solution is reached, solution can be objectively evaluated as right or wrong, it belongs to the type of problems that can be dealt with in similar way, has solutions that can be easily tried and abondoned and has a limited set of alternative solutions. According to Conklin (2005), "it may be convenient to describe a problem as wicked or tame, but it's not binary - most problems have degrees of wickedness" (p. 19). Therefore, the complicated problem of integrating sustainability into curricula of higher education although a seemingly tame problem is both technically difficult and may contain several wicked subproblems. 
One of the significant features of post-normal science is transdisciplinarity. It refers to all that interweaves several disciplines, moves across them, is situated in between them or outside the limits of these disciplines to include physical, living, and social systems, with their infinite implications. Transdisciplinary study suggests the synergistic collaboration between two or more disciplines, as to create theoretical and methodological integrated innovations providing such solution to common problem that reaches far behind the specific approaches of involved disciplines. Representatives of each single discipline actually operate outside the boundaries of his/her field trying to grasp the addressed problem as a whole, instead of focusing on one peculiar aspect of the problem relevant to his/her discipline. Unlike interdisciplinarity and multidisciplinarity, transdisciplinarity requires that researchers from different fields cooperate in creating new science while studying issues common for these disciplines, engaging in common research projects and developing methodology permitting the reintegration of knowledge (Sommerville \& Rapport, 2002). Speaking about the expertise of each member of the research team, the transdisciplinary approach is also possible if one researcher, having an expertise in several fields, explores the relevant problem, or if several researchers working together each have an expertise in several fields. Transdisciplinarity can be viewed both as the type of interdisciplinary research applying scientific and non-scientific sources or practices, and also, the novel form of learning and problem solving grounded on cooperation among different scientific disciplines and fields of social life so as to cope with different challenges of contemporary life (McGregor, 2004). Today it is already clear that transdisciplinary research has moved "beyond the bridging of divides within academia to engaging directly with the production and use of knowledge outside of the academy" (Toomey, Markusson, Adams, \& Brockett, 2015, p.1). For instance, dealing with the issue of social inequality, interdisciplinary teams of researchers, possibly, would consider wisdom of local community and try to elaborate an integrated and innovative perspective, rising above the specific approaches and methodologies of each discipline (sociology, economics, psychology, etc.). Transdisciplinary research practices are responsible for real life needs and prioritize the problem at the focus of research over the specific concerns, theories or methods of disciplines (Leavy, 2011). Whereas transdisciplinarity is oriented toward the real life problems, it should not design its own terminology and specific methods but try to use a language shared by many disciplines and present the results in a form understandable by civil society (Brandt et al., 2013).

Methodologically, transdisciplinary research follows responsive or iterative methodologies and requires innovation, creativity, and flexibility and often employs participatory research design strategies (Leavy, 2011). While interdisciplinary research may unite data from two or more disciplines, usually employing one epistemological method such as quantitative modeling, in contrast, transdisciplinary research includes all of the necessary epistemologies and methodologies, spanning the physical, living and social realms, usually employing both quantitative data and qualitative theory (Wells, 2013). Transdisciplinary research is often action-oriented entailing linkages not only across disciplinary boundaries, but also between methods and practices (Lawrence \& Despres, 2004). However, as the literature shows, contemporary science encounters many subjective and objective hindrances to the successful performance of such (Grey, 2008; Young, 2000). Since this paper does not allow for the more extensive description of transdisciplinary research in general, follow-up for the interested parties could be found in 15 propositions conceived by the editors of the "Handbook of Transdisciplinary Research" 
(Wiesmann et al., 2008) who describe the essence, scope and process of transdisciplinary research, suggest hints of how to deal with problems of this approach, and define resources needed to face the scientific, institutional and societal challenge.

R. Lawrence and C. Despres have linked transdisciplinarity and complexity invoking that transdisciplinarity relates to complexity in a strive to overcome the fragmentation of knowledge and such features as hybridity, non-linearity and reflexivity transcending the structures of academic disciplines (Lawrence $\&$ Despres, 2004). E. Morin advanced complexity as method through an exposition of complexity as transdisciplinary (see in Wells, 2013). Complexity is intertwinned with the processes of emergence that are omnipresent in real life, so transdisciplinarity is the best approach to deal with such processes (Kline, 1995).

Over the last few decades transdisciplinarity has grown rapidly in several fields, such as medical and health research, environmental research, sustainability research, educational research, policy research and social research (Leavy, 2011). Complexity theories can be viewed as a holistic transdisciplinary framework and provide an integral view of sustainability issues, which may contribute to the comprehension and guidance for problem solutions in economics, science, technology, ethics, politics, and policy. Complexity for sustainability calls for an articulation of both disciplinary, interdisciplinary and transdisciplinary approaches. Transdisciplinarity is necessary to sustainability in assessing not just the scientific aspects of global change, but also the social aspects politics, ethics, economics, and social theories (Wells, 2013). So to summarise, we can state that an integral view on the contemporary mission for science, institutions and community looking for the research paradigm for sustainability asks for post-normal science able to deal with a wicked problem of sustainability within a transdisciplinary framework of complexity paradigm.

\section{Complexity as a Research Paradigm for Education}

Coming back to the idea that complexity thinking should work with any system, we can not deny the potential of this paradigm in social sciences, humanities and education. In fact, the principle of self-organization, essential for complexity, is self-evident in these systems thus showing that applications of merely natural science methods to these fields that deal with wicked problems (e.g., poverty, equality, political instability, health care, transforming education, etc.) are destined for failure. Central qualities of the social systems like subjectivity and the ability for radical changes in ideas, attitudes, worldviews, behaviors ask for other relevant methods and research strategies.

Fleener (2016) has proposed the definition of educational research as a research asking "why", "what" and "how" regarding the preparation of students as a next generation of thinkers and doers. Currently educational research is searching for the answers on these questions through the positivist, postpositivist and postmodernist paradigm envisaging the usage of qualitative, quantitative and mixed method research (Pipere, Veisson, \& Salite, 2015). Such an approach illustrates the striving of researchers to accomodate both the need for complexity thinking and rising demand to inform the educational practice and policy in their effort toward normative aims. Paradoxically, it is complexity thinking that allows for different discourses to be used simultaneously in educational studies. The analysis of complexity paradigm and several complexity principles in relation to education and educational research is already presented by several authors 
(see more in Davis \& Sumara, 2006; Mason, 2008; Radford, 2006; Reigeluth, 2008, etc.). To focus just on a few aspects that can be important in a context of this paper, the author will cover the complexity of educational situations, the research paradigm, methods and forms as well as the aims of educational research and connection between the research and practice.

Educational researchers study nested, evolving and intertwining phenomena (Davis \& Sumara, 2008) or, to put it simply, all principles of complex dynamic systems depicted in Table 1 should be considered in some way informing educational research from the perspective of complexity. All educational discourse containing human cultural frameworks, institutions and constructions can be seen as "consisting of multiple interconnecting elements, continuously evolving in an unpredictable environment that itself consists of a multiplicity of further elements " (Radford, 2006, p. 184). These interconnecting elements or variables are connected in non-linear and dynamic way so that the relationships between the effect and cause are non-symetrical and disproportional. According to Kuhn (2008), both individuals (learners, educators, educational administrators and policy-makers), associations of individuals (classes, schools, universities, educational associations) and human endeavour like educational research itself are multi-dimensional, non-linear, interconnected, far from equilibrium and unpredictable. Thereby the problems in educational endeavour could be reasonably identified as wicked problems that need to be approached by the perspective of post-normal science.

As it was implicated before, the educational research from the complexity point of view is necessarily connected with theoretical, paradigmatic and methodological pluralism. Complexity paradigm asks for the qualitative research complementing the quantitative studies and establishment of hermeneutic social science that would describe and explain the dynamics of social systems as complex adaptive systems mainly in terms of communication and information flow and their constitutive impact on clusters of possible causes and effects (Horn, 2008; Radford, 2008).

In regard to the research methodology, the authors who examine complexity of educational research, mainly focus on qualitative research, including the case studies, based on interpretative and interactionist epistemology, and participatory, multi-perspective and collaborative (self-organized), partnership-based forms of research implicating the equal dialogue between the initiators and participants of the process (Morrison, 2008). Thus the changes in educational research designate the move away from causal models toward modelling local connections between actors, practices and events on all levels of organization. Again, the simplistic solutions and single interventions that are frequently suggested by "normal science" should be replaced or at least complemented by "the recognition of the need for coordinated changes throughout the system and to its constraining and enabling contexts and resources" (Lemke \& Sabelli, 2008, p. 122). Davis (2008) argues that complexity oriented educational research should strive to integrate previously disintegrated phenomena like knower and knowledge, representation and presentation, different phenomenal levels of explanation (transphenomenality), multiple discursive perspectives (interdiscursivity) and various disciplinary viewpoints (transdisciplinarity). Let's reveal some deeper connections of the last three concepts with educational research.

Transphenomenality involves sort of a level jumping from direct appearance of phenomena to some explanation beyond this appearance, for instance, in education it could be found trying to explain the learning simultaneously from the perspective of 
genetics, personal experience of learner, social interactions, cultural context, interaction between person and the world, etc.

Although the interdiscursivity itself comes from the post-structuralist theory and initially has been related to linguistic analysis showing how discourses intersect, overlap, and interlace in a framework of text, in given context of educational research interdiscursivity could be interpreted as "the use of elements in one discourse and social practice which carry institutional and social meanings from other discourses and social practices" (Candlin \& Maley, 1997, p. 212). Following the example of learning, the aforementioned perspectives could be viewed upon from the intermingled discourses of analytic science, phenomenology, symbolic interactionism, cultural studies and philosophy (Davis, 2008).

Transdisciplinarity in educational research is justified both from the perspective of education as a field endowed with questions closely related to real life problems concerning each individual and involving multidimensional discourses across a large number of diverse disciplines, for instance, cybernetics, biology, neurosciences, philosophy, linguistics, psychology, sociology, etc. Transdisciplinary approaches to educational research allow one to maintain the disciplinary openness that is so important for such complex social system as education. Cronin (2008) proposes four core characteristics of transdisciplinary research from which the first two have gained wider recognition: 1) a focus on lifeworld problems, 2) transcending and integrating disciplinary paradigms, 3) participatory research and 4) the search for the unity of knowledge beyond the disciplines. Educational research today can be, possibly, appropriated through the first three criteria as they focus on socially recognized problems, integrate paradigms from different disciplines and, lately, as it was already mentioned, they have been associated with participatory approaches to inquiry in educational domain. Participatory educational research in terms of specific research methodology as participatory action research (Cammarota \& Fine, 2008; McTaggart, 1997; Kemmis, 2006) has been popularized through journals, books, projects, academic courses and workshops. However, consilience as coined by biologist Wilson (1998), explaining the search for the unity of knowledge beyond the disciplines, in educational research is probably at its initial stage (e.g., Lim, 2016).

So, to conclude, the educational research in terms of complexity is descriptive and explanatory research within a range of interpretive possibilites and broad perspective on development with primarily situation-specific decisions (Horn, 2008; Radford, 2006, 2008). In line with Radford (2008), the complexity of social reality as well as rendered explanatory frameworks mean that these are invariably fragile and open to continuous reinterpretation. This indicates that post-normal science can not clearly predict the success of educational interventions toward one or another objective thus disappointing many practitioners and decision-makers working towards the normative aims of education in the current era of effectivity, productivity and accountability (Hursh, 2005). The infinite number of variables and relative significance of them all is hard to measure from a knowledge of initial conditions therefore blurring the clear links between intervention and result (Radford, 2008). At the same time, one could eventually agree with suggestion by Davis (2008) about the urgent necessity to join the descriptive and pragmatic goals of educational research moving beyond description of complex phenomena toward deliberate attempts to prompt the emergence and affect the character of phenomenon. 


\section{Complexity as a Research Paradigm for Sustainability Education}

Before delving into the nuances of the research, let's have a short critical view into the essence of sustainability education. Following Sterling (2004), the term 'sustainability education' (SE) will be used as a unifying term including environmental education (EE), education for sustainable development (ESD), education for sustainability (EFS) and education for a sustainable future (ESF). To begin with, the main characteristics of SE relevant to educational and philosophical discourse will be highlighted, then educational research for sustainability will be detailed in some degree. Finally, the complexity perspective on SE research will be outlined emphasizing its transdisciplinary nature.

SE is essential for students to appreciate, understand and think critically about complex environmental, social and economic problems (Huckle \& Sterling, 1996). According to Huckle (1996), it is an alternative general educational paradigm, that enables the fundamental reorientation of educational aims and education as a whole toward reaching more sustainable world. He notes that it is "both critical and transformative education, allowing learners to consider the merits of a wide range of alternative technologies, forms of social organization, models of development and ideas and values, and to form their own opinions regarding the meaning of sustainability and its implications for their lives and their relations with the rest of human and non-human nature" (p. xxii).

Oriented toward the change of educational paradigm, current SE still holds a lot of contradictions and dichotomies like one between realism and idealism in worldview, behaviorism and constructivism in learning theory and content/process as well as transmission/transformation in terms of methodology (Sterling, 2004). The integrated and theoretically sound description of SE key points suggests that SE is based on realist/ idealist (relational) ontology, participatory epistemology and participative/systemic theory of learning. Based on intrinsic and transformative values, SE stresses the transformative learning experiences and pedagogy focusing on meaning making according to context while seeking wholeness and sustainability. SE serves as remedial, developmental and transformative agency looking for the change towards contextually appropriate balance between autonomy and integration in and between different levels of systems (Sterling, 2004). In SE the term sustainability is seen as a feature describing the entire learning process. According to Sterling (2004), this is not so much education for specific outcomes of sustainable development or even less - the education about sustainability, it is education as sustainability advancing critical, systemic and reflective thinking, creativity, self-organization and adaptive management.

The integral part of educational research - research in SE can not be viewed as a fully established yet or extensively discussed in literature, although the last years have designated the move toward more sophisticated approaches and appropriate perspectives. In terms of SE research on different levels of formal education, it seems that the most extensive development recently has been noticed in educational research for sustainability in higher education, than - in elementary and secondary stages of education, less activity has been observed in preschool education research (more common in US and Finland). Also, research in SE can be conducted in non-formal and informal educational settings. One of the few documents containing the programmatic review of research in ESD The UNESCO Guidelines for creating a national ESD research agenda and plan (UNESCO, 2012), suggests several research directions (rather than research themes in the classical sense) that had been invoked during the early years of UNESCO Decade of Education 
for Sustainable Development. The research should start with the theoretical background of ESD, than track the progress of ESD, identifying and analysing contribution of ESD to society and educational system while keeping in sight supporting and inhibiting factors as well as documenting success and failures. Usage of research-derived data on ESD to inform decisions was also considered an important direction (UNESCO, 2012). In a view of surveyed researchers (Pipere, Reunamo, \& Jones, 2010), the research topics for ESD research should be focused at the monitoring and examination of the current situation, transformation of human awareness and actions towards more sustainable life and responsibility towards the world aiming to develop models for personal and a societal future life. Some researchers admit that their research considers sustainability as a sign allowing to see education in a new light (awareness, self-regulation, world views, etc.), recognize the need for the requisite evaluation of ESD (Kopnina \& Meijers, 2014) and development of contextualized educational models (Stephens, Hernandez, Roman, Graham, \& Scholz, 2008).

Speaking about the methodology of educational research for sustainability, it is widely recognized that similarly as in educational research in general both qualitative and quantitative approaches can be used as well as the mixed methods designs. Also, the action research and various types of participatory research become more and more common. Drawing from the Reunamo' model of agentic perspective (Reunamo \& Pipere, 2011) adapted for the ESD research it can be said that "in the ESD research qualitative studies should be aimed for the understanding of the motifs and discourse of sustainable development, quantitative research evidently will help to obtain a valid and generalized picture of sustainable development and its mechanisms, theoretic research will try to create tools to connect past and future, while participative inquiry will deepen the researchers' awareness of their role as the producers of cultural content and ingredients of sustainable development" (Pipere, Veisson, \& Salite, 2015). In terms of research methods, qualitative research in this field traditionally uses interviews (Corney, 2006) and focus groups (Barth, Godemann, Rieckmann, \& Stoltenberg, 2007), quantitative studies uses scales and quantitative surveys (Kopnina, 2013), theoretic research analyses the theoretical underpinnings and critical discourse of ESD (Kopnina \& Meijers, 2014; Tillmanns, Holland, Lorenzi, \& McDonagh, 2014), while participative studies commonly include the educational action research (Gedžūne \& Gedžūne, 2011; Salìte, 2008) and other forms of participatory inquiry (Gayford, 2003). Mixed method studies integrate the typical quantitative and qualitative methods applied in SE research (McNamara, 2010). In terms of case studies as a specific research design, initially they were criticised for their incapability to transform the practice, especially in higher education (Corcoran, Walker, \& Wals, 2004; Kyburz-Graber, 2004), later also more practice oriented studies was commenced (e.g., Higgs \& McMillan, 2006; Holmberg et al., 2008).

Recently several attempts to develop a complexity perspective on SE were initiated more in terms of aims, structure, processes, outcomes, etc. of SE, not so much in relation to research on SE. Already in the discourse on SE used by Sterling (2004) and other scholars one can notice a repertoire and specific vocabulary matching the main principles of complex dynamic systems (see in Table 1). Also, for example, complexity discourse in ESD has been extended lately employing the concept of rhizome or rhizomatic network structure (notion developed by G. Deleuze and F. Guattari (1987)), that shows us the ideal way of systems development. Rhizomatic structures (such as tubers or moss) can make connections between any two points on their surface thus resembling kind of 
transcontextuality at work. The principles of the rhizome (connection, heterogeneity, multiplicity, signifying rupture, cartography and decalcomania) have been examined in the context of six processes necessary for effective ESD (Tilbury, 2011), namely, collaboration, dialogue, 'whole system' engagement, innovation within curricula, teaching and learning and active and participatory learning (Tillmanns, Holland, Lorenzi, \& McDonagh, 2014). This reconceptualisation of ESD as rhizomes enables us to perceive the reality of education as complex interconnected multiplicities.

Coming to this point in the paper, it already might be apparent that educational research for sustainability similarly as educational research per se and all research dealing with social systems and sustainability is inevitably connected to complexity as a research paradigm. As stated above, sustainability as a wicked problem should be viewed through the lens of post-normal science and all social systems and institutions dealing with sustainability in any form also should follow this way. Since the transformation of education in any direction, not to mention transformation of education toward sustainability, can also be regarded as a wicked problem, educational researchers exploring this transformation in an ultimate sense are eligible to approach education striving for sustainability as a complex dynamic system and hence to perform their studies based on the principles of these systems and features of complexity paradigm like transdisciplinarity, transphenomena and interdiscursivity. Following this line we could also say that wicked problems ask for transcontextual thinking - connecting things that usually are not associated in given context or thinking creatively and unconventionally.

Ultimately, it seems that educational research for sustainability can successfully use main principles of complex dynamic systems (in Table 1) as well as other principles and perspectives of complexity paradigm. All that was said above regarding the educational research from the complexity point of view, can be applied also to the educational research for sustainability. Next, one of the most promising and functional ways to describe complexity as a research paradigm for SE - using the discourse of transdisciplinarity, will be in focus.

Educational research for sustainability matches at least three core elements of transdisciplinary research (Cronin, 2008), namely, it focuses on lifeworld problems since education is both the most individual and global lived experience of humanity reproduced every minute in every part of the world, it is searching for transcendence and integration of disciplinary paradigms and it actively uses the approaches and methods of participatory inquiry as seen above. The research in SE as transdisciplinary research can be organized using Stokols' (2006) programmatic directions for the scientific study of transdisciplinary research and community action that suggests three types of collaboration. These three types can be detailed and complemented with two other types of collaboration thus distinguishing two groups of collaboration:

1) Cross-disciplinary collaboration for SE research:

- Disciplines dealing with sustainability and its physical, biological, and ecological context;

- Disciplines dealing with social systems in general: sociology, politology, communication, community psychology, social work, social psychology, health psychology, etc.;

- Disciplines dealing with education as social system: educational science, educational philosophy, environmental education, educational psychology, cognitive psychology, social (community) pedagogy, etc. 
2) Cross-institutional collaboration for SE research:

- Collaboration among researchers from multiple fields and community practitioners representing diverse professional and lay perspectives (e.g., researchers in environmental education, social psychology, community workers and representatives of community and national media);

- Collaboration among research organizations and institutions across local, regional, national and international levels;

- Collaboration among educational institutions across local, regional, national and international levels;

- Collaboration among community organizations across local, regional, national, and international levels.

It should be noticed that also the combination of several types of cross-collaboration is possible, besides, as mentioned earlier, in some cases even a single researcher, having expertise in several disciplines can conduct transdisciplinary research.

In terms of research outcomes, educational research for sustainability should strive for three types of knowledge peculiar for transdisciplinary research (Hadorn et al., 2008):

1) System knowledge could bring the knowledge about the current system of SE, frame the most significant issues in this field and systemic interpretation of this knowledge in accordance with various goals of researchers and other involved groups;

2) Target knowledge designates the desired future status of SE recognizing the multiple norms and values that will depend on researchers and other participants' perceptions of SE as complex system, their understanding about the systems relations and options for change;

3) Transformation knowledge in this field would help practitioners to make the transition to the target status of SE that will ask for social, political, legal, cultural, institutional and other changes.

The integration between the transdisciplinarity, research methodology and practice has brought the approach of transdisciplinary case study that could be viewed as a combination of research, learning and application. Some attempts to apply this approach to the research for sustainability and related issues are already made by several authors (Stauffacher, Walter, Lang, Wiek, \& Scholz, 2006; Stauffacher, Flüeler, Krütli, \& Scholz; 2008; Wiek, 2007).

\section{Concluding Reflections}

Like the most issues in environmental sustainability, also the "educational" sustainability can be portrayed by high decision stakes and high systems uncertainties. The future of the world depends on the competences of young generation to think and live sustainably, make sustainable choices and difficult decisions in the context of rising uncertainty, insecurity and ambiguity. Moreover, the arena of education has always been fraught with miriades of factors, networks, contexts associated with unpredictability, adaptation, self-organization, etc. depending of large number of stakeholders and their relationships. 
Diamond (2003, p. 23) lists four reasons for the collapse of societies: these are failures to 1) anticipate problems, 2) perceive problems, 3) engage in problem-solving and 4) solve problems despite engaging with them. Unsustainability of ecological, political, social, cultural and educational systems which is clearly revealed in our contemporary relationships with these problems shows that we need new paradigms and innovative approaches to the traditional and long time established dimensions of human life. However, as it might be inferred from the analysis above, it would also lead to unsustainability if we unanimously declare every problem encountered as a wicked problem and deal with it only as complex system within a framework of transdisciplinarity desperately looking for required collaborators in other disciplines, institutions or community. Complexity, wickedness, transdisciplinarity and the like should be always viewed on a certain scale or range according to the real world context, common sense and sometimes even intuitive grasping of situation.

This paper has presented the conceptual analysis aimed toward the justification of complexity thinking to explore SE. To build the solid argumentation, the paper started with the definitions of complexity and main principles of complex dynamic systems followed by implications of complexity thinking for sustainability, education, and SE. The research paradigm as looked through the concepts of post-normal science, wicked problems and transdisciplinarity in sustainability and related issues inevitably pointed to the necessity of complexity thinking. Educational research for sustainability could benefit by the complexity paradigm based on transdisciplinarity, transphenomenality, transcontextuality, interdiscursivity and principles of complex dynamic systems. Finally, the transdisciplinary nature of educational research for sustainability has been elaborated in a more detailed way. This paper itself can be perceived as an example of transdisciplinary exercise connecting different disciplines that happen to be integrated in the research interests, research and teaching practice of the author.

The idea about this paper emerged after finishing the chapter on complexity for the book "Research: Theory and Practice" (Pipere, 2016). The intention to bridge the innovative ideas on complexity and educational research on sustainability seemed very reasonable, logical and clear. However, finishing this work it is evident that this has been just the beginning of a large work that sometimes may seem not reasonable at all, too complex, uncertain, unpredictable and asking for inexhaustible creativity. Considering if only the pressing necessity to merge the description of complex phenomena in $\mathrm{SE}$ and urge from the practitioners and politics to provide the normative knowledge for effective and swift changes in human behaviour, it looks like the complexity paradigm applied to educational research in its essence is very taxing on researchers and practitioners. It asks from them the extention of expertise in other fields, assuming larger responsibility for practitioner-based inquiry and applying contextual theories and models. The educational research and educational practice could be an aspects of the same project - "expanding the space of human possibility by exploring the space of the existing possible" (Davis, 2008, p. 168). Hopefully, the ideas of this paper might facilitate also the solution of the ethical dilemma presented in the introduction of this paper.

One of the limitations of given approach used in the paper relates to the lack of larger emphasis and more detailed elaboration on the complexity principles for the educational research for sustainability. However, this can not be attained without proper preparation of mindset and gradual transformation of traditional discourse currently used in a majority of research papers in this field. The present situation bears indications 
that the researchers and practitioners need a certain period of adaptation to the new ideas and approaches making the acceptance of innovations and mental transformations more easy. However, it can be also viewed as our collective cognitive responsibility (Scardamalia, 2002) to make such an adaptation in our views and ideas on research.

Further avenues of development in respect to the reasoning presented in this paper point to the detailed analysis and justification of research paradigm of complexity in educational studies as well as in a field of SE per se and educational research for sustainability. The thorough and systematic theoretical analysis of the principles of complex dynamic systems as a potential context for the future development of educational research for sustainability for the time being should be complemented with the relevant empirical inquiry. Since sustainability, education and research can all be viewed as the complex problems, they are also open systems. And so this paper probably also could be viewed as a wicked problem leaving many important questions open for feedback, further investigation and collaborative endeavours. Besides, all complex systems are creative in their nature, but if we have creativity, we also have a hope - for the world and all of us.

\section{References}

Barth, M., Godemann, J., Rieckmann, M., \& Stoltenberg, U. (2007). Developing key competencies for sustainable development in higher education. International Journal of Sustainability in Higher Education, 8(4), 416-430.

Brandt, P., Ernst, A., Gralla, F., Luederitz, C., Lang, D. J., Reinert, J. N. B., Abson, D. J., \& von Wehrden, H. (2013). A review of transdisciplinary research in sustainability science. Ecological Economics, 92, 1-15.

Bruner, J. (1960). The process of education. Cambridge, MA: Harvard University Press.

Bunnin, N., \& Yu, J. (2004) (Eds.). The Blackwell dictionary of Western philosophy. Blackwell Publishing.

Burns, A., \& Knox, J. (2011). Classrooms as complex adaptive systems: A relational model. The Electronic Journal for English as a Second Language, 15(1), 1-25.

Camaren, P., \& Swilling, M. (2014). Linking complexity and sustainability theories: Implications for modeling sustainability transitions. Sustainability, 6, 1594-1622.

Cammarota, J., \& Fine, M. (Eds.) (2008). Revolutionizing education: Youth participatory action research in motion. Routledge Taylor \& Francis Group.

Candlin, C. N., \& Y. Maley (1997). Intertextuality and interdiscursivity in the discourse of alternative dispute resolution. In B.-L. Gunnarsson et al. (Eds.), The construction of professional discourse (pp. 201-222). London, Longman.

Checkland, P. (1991). Systems thinking: Systems practice. Chichester, Wiley.

Conklin, J. (2005). Dialogue mapping: Building shared understanding of wicked problems. Chichester: J.W. Wiley \& Sons.

Corcoran, P. B., Walker, K. E., \& Wals, A. E. J. (2004). Case studies, makeyourcase studies, and case stories: A critique of case-study methodology in sustainability in higher education. Environmental Education Research, 10(1), 7-21.

Corney, G. (2006). Education for sustainable development: An empirical study of the tensions and challenges faced by geography student teachers. International Research in Geographical and Environmental Education, 15(3), 224-240.

Cronin, K. (2008). Transdisciplinary research (TDR) and sustainability. Overview report prepared for the Ministry of Research, Science and Technology (MoRST). 
Dann, Z., \& Barclay, I. (2006). Complexity Theory and knowledge management application. The Electronic Journal of Knowledge Management, 4(1), 11-20.

Davis, B. (2008). Complexity and education: Vital simultaneities. In M. Mason (Ed.), Complexity Theory and the philosophy of education (pp. 46-61). Wiley-Blackwell.

Davis, B., \& Sumara, D. (2006). Complexity and education: Inquiries into learning, teaching, and research. Routledge.

Davis, B., \& Sumara, D. (2008). Complexity as a theory of education. Transnational Curriculum Inquiry, 5(2). Retrieved from: http://nitinat.library.ubc.ca/ojs/index. $\mathrm{php/tci}$

Deleuze, G., \& Guattari, F. (1987). A thousand plateaus: Capitalism and schizophrenia. Minneapolis, MN: The University of Minnesota Press.

Diamond, J. (2005). Collapse: How societies choose to fail or succeed. New York: Viking Books.

Doll, W. E. Jr., Fleener, M. J., Trueit, D., \& Julien, J. St. (2006) (Eds.). Chaos, complexity, curriculum, and culture: A conversation (Complicated conversation). Peter Lang Inc., International Academic Publishers.

Espinosa, A., \& Walker, J. (2011). A complexity approach to sustainability: Theory and application (Series on Complexity Science). World Scientific Publishing Company.

Fleener, M. J. (2016). Re-searching methods in educational research: A transdisciplinary approach. In M. Koopmans \& D. Stamovlasis (Eds.), Complex dynamic systems in education: Concepts, methods and applications (pp. 9-21). Springer.

Funtowicz, S., \& Ravetz, J. (1993). Science for the post-normal age. Futures, 25(7), $739-755$.

Garnett, P. W. (1997). Chaos theory tamed. Joseph Henry Press.

Gayford, C. (2003). Participatory methods and reflective practice applied to research in education for sustainability. Canadian Journal of Environmental Education, 8(1), 129-143.

Gedžūne, I., \& Gedžūne, G. (2011). Exploring and promoting ecological consciousness in teacher education: The possibilities of Educational Action Research in education for sustainable development. Journal of Teacher Education for Sustainability, 13(1), 43-61.

Gershenson, C. (2013). The implications of interactions for science and philosophy. Foundations of Science, 18(4), 781-790.

Glouberman, S., \& Zimmerman, B. (2002). Complicated and complex systems: What would successful reform of medicare look like? Discussion paper No 8. Commission on the Future of Health Care in Canada.

Gray, B. (2008). Enhancing transdisciplinary research through collaborative leadership. American Journal of Preventive Medicine, 35(2 Suppl), 124-132.

Guillaume, J. H. A. (2014). Managing uncertainty in modelling of wicked problems: Theory and application to Sustainable Aquifer Yield. Doctoral dissertation. Australian National University.

Hadorn, G. H. et al. (Eds.). (2008). Handbook of transdisciplinary research. Springer. Harris, G. (2007). Seeking sustainability in an age of complexity. Cambridge University Press.

Heylighen, F. (2008). Complexity and self-organization. In M. J. Bates \& M. N. Maack (Eds.), Encyclopedia of library and information sciences, vol. 2 (pp. 1215-1224). Oxford: Taylor and Francis. 
Higgs, A. L., \& McMillan, V. M. (2006). Teaching through modeling: Four schools' experiences in sustainability education. The Journal of Environmental Education, 38(1), 39-53.

Holland, J. H. (1998). Emergence: From chaos to order. Oxford University Press.

Holman, P. (2010). Engaging emergence: Turning upheaval into opportunity. BerrettKoehler Publishers.

Holmberg, J., Svanström, M., Peet, D.-J., Mulder, K., Ferrer-Balas, D., \& Segalàs, J. (2008). Embedding sustainability in higher education through interaction with lecturers: Case studies from three European technical universities. European Journal of Engineering Education, 33(3), 271-282.

Horn, J. (2008). Human research and complexity theory. In M. Mason (Ed.), Complexity Theory and the philosophy of education (pp. 124-136). Wiley-Blackwell.

Huckle, J. (1996). Introduction to the 2014 e-book edition. In S. Sterling \& J. Huckle (Eds.). Education for sustainability. Routledge.

Huckle, J., \& Sterling, S. (Eds.) (1996). Education for sustainability. London: Earthscan.

Hursh, D. (2005). Neo-liberalism, markets and accountability: Transforming education and undermining democracy in the United States and England. Policy Futures in Education, 3, 3-15.

Johnson, N. F. (2009). Simply complexity: A clear guide to complexity theory. Oneworld Publications.

Kemmis, S. (2006). Participatory action research and the public sphere. Educational Action Research, 14(4), 459-476.

Kline, S. J. (1995). Conceptual foundations for multidisciplinary thinking. Stanford University Press.

Knight, G. R. (2008). Issues and alternatives in educational philosophy. Andrews University Press.

Kopnina, H. (2013). Evaluating education for sustainable development (ESD): using Ecocentric and Anthropocentric Attitudes toward the Sustainable Development (EAATSD) scale. Environment, Development and Sustainability, 15(3), 607-623.

Kopnina, H., \& Meijers, F. (2014). Education for sustainable development (ESD): Exploring theoretical and practical challenges. International Journal of Sustainability in Higher Education, 15(2), 188-207.

Kuhn, L. (2008). Complexity and educational research: A critical reflection. In M. Mason (Ed.), Complexity Theory and the philosophy of education (pp. 169-180). WileyBlackwell.

Kyburz-Graber, R. (2004). Does case-study methodology lack rigour? The need for quality criteria for sound case-study research, as illustrated by a recent case in secondary and higher education. Environmental Education Research, 10(1), 53-65.

Lawrence, R. J., \& Despres, C. (2004). Futures of transdisciplinarity. Futures, 36(4), 397-405.

Leavy, P. (2011). Essentials of transdisciplinary research: Using Problem-centred methodologies. Left Coast Press, Inc.

Lemke, J. L., \& Sabelli, N. H. (2008). Complex systems and educational change: Towards a new research agenda. In M. Mason (Ed.), Complexity Theory and the philosophy of education (pp. 112-123). Wiley-Blackwell.

Lim, S.-S. (2016). Towards consilience in science of learning: Data as currency for collaboration. Npj Science of Learning, 1, 16009. 
Logan, R. K., \& Schumann, J. H. (2005). The symbolosphere, conceptualization, language, and neo-dualism. Semiotica, 155(1-4), 201-214.

Mantzavinos, C. (2016). Hermeneutics. In E. N. Zalta (Ed.), The Stanford encyclopedia of philosophy. Retrieved from: http://plato.stanford.edu/archives/fall2016/entries/ hermeneutics

Mason, M. (2008). Complexity Theory and the philosophy of education. Wiley-Blackwell.

Maton, K. (2014). Building powerful knowledge: The significance of semantic waves. In B. Barrett \& E. Rata (Eds.), Knowledge and the future of the curriculum: International studies in social realism (pp. 181-197). London: Palgrave Macmillan.

McGregor, S. L. T. (2004). The nature of transdisciplinary research and practice. Kappa Omicron Nu Human Sciences Working Paper Series [online]. Retrieved from: http://www.kappaomicronnu.com/hswp/archive/transdiscipl.pdf

McNamara, K. H. (2010). Fostering sustainability in higher education: A mixed-methods study of transformative leadership and change strategies. Environmental Practice, $12(1), 48-58$.

McTaggart, R. (1997). Participatory action research: International contexts and consequences. Albany, NY: State University of New York Press.

Morrison, K. (2008). Educational philosophy and the challenge of complexity theory. In M. Mason (Ed.), Complexity Theory and the philosophy of education (pp. 1631). Wiley-Blackwell.

Newell, C. (2008). The class as a learning entity (complex adaptive system): An idea from complexity science and educational research. SFU Educational Review, 2(1), $5-17$.

Norberg, J., \& Cumming, G. S. (2008). Complexity theory for a sustainable future. Columbia University Press.

Osberg, D., \& Biesta, G. (2010). (Eds.). Complexity theory and the politics of education. Sense Publishers.

Peterson, H. C. (2014). Sustainability: A wicked problem. In E. Kebreab (Ed.), Sustainable animal agriculture (pp. 1-9). CABI.

Pipere, A. (2016). (Cerams) saprotami par komplicētību [(Hopefully) comprehensibly about the complexity]. In K. Mārtinsone, A. Pipere, \& D. Kamerāde (Eds.). Pètnieciba: Teorija un prakse [Research: Theory and practice]. Rìga: RaKa. In Press.

Pipere, A., Reunamo, J., \& Jones, M. (2010). Perceptions of research in education for sustainable development: An international perspective. Discourse and Communication for Sustainable Education, 1, 5-24.

Pipere, A., Veisson, M., \& Salīte, I. (2015). Developing research in teacher education for sustainability: UN DESD via the Journal of Teacher Education for Sustainability. Journal of Teacher Education for Sustainability, 17(2), 5-43.

Poli, R. (2013). A note on the difference between complicated and complex social systems. Cadmus: Promoting leadership in thought that leads to action, 2(1), 142-147. Retrieved from: http://www.cadmusjournal.org/files/pdfreprints/vol2issue1/reprintcj-v2-i1-complex-vs-complicated-systems-rpoli.pdf

Radford, M. (2006). Researching classrooms: Complexity and chaos. British Educational Research Journal, 32(2), 177-190.

Radford, M. (2008). Complexity and truth in educational research. In M. Mason (Ed.), Complexity Theory and the philosophy of education (pp. 137-149). Wiley-Blackwell. 
Reigeluth, C. M. (2008). Chaos theory and the sciences of complexity: Foundations for transforming education. In B. Despres (Ed.), Systems thinkers in action: A field guide for effective change leadership in education. New York: Rowman \& Littlefield.

Reunamo, J., \& Pipere, A. (2011). Doing research on education for sustainable development. International Journal of Sustainability in Higher Education, 12(2), 110-124.

Riccucci, N. M. (2008). The logic of inquiry in the field of public administration. In G. J. Miller \& K. Yang (Eds.), Handbook of research methods in public administration (pp. 3-12). Taylor and Francis group, LLC.

Salite, I. (2008). Educational Action Research for sustainability: Constructing a vision for the future in teacher education. Journal of Teacher Education for Sustainability, $10,5-16$.

Sartori, G. (1984). Guidelines for concept analysis. In G. Sartori (Ed.), Social science concepts: A systematic analysis (pp. 15-85). London: Sage.

Scardamalia, M. (2002). Collective cognitive responsibility for the advancement of knowledge. In B. Smith (Eds.), Liberal education in a knowledge society (pp. 67-98). Chicago: Open Court.

Sommerville, M. A, \& Rapport, D. J. (Eds.) (2002). Transdisciplinarity: Recreating integrated knowledge. McGill-Queens University Press, Montreal QC, Canada.

Stauffacher, M., Flüeler, T., Krütli, P., \& Scholz, R. W. (2008). Analytic and dynamic approach to collaboration: A transdisciplinary case study on sustainable landscape development in a Swiss Prealpine Region. Systemic Practice and Action Research, 21(6), 409-422.

Stauffacher, M., Walter, A. I., Lang, D. J., Wiek, A., \& Scholz, R. W. (2006). Learning to research environmental problems form a functional socio-cultural constructivism perspective: The transdisciplinary case study approach. International Journal of Sustainability in Higher Education, 7(3), 252-275.

Stephens, J. C., Hernandez, M. E., Romįn, M., Graham, A. C., \& Scholz, R. W. (2008). Higher education as a change agent for sustainability in different cultures and contexts. International Journal of Sustainability in Higher Education, 9(3), 317-338.

Sterling, S. (2004). An analysis of the development of sustainability education internationally: Evolution, interpretation, and transformative potential. In J. Blewitt \& C. Cullingford (Eds.), The sustainability curriculum: The challenge for higher education (pp. 43-62). London: Earthscan.

Stokols, D. (2006). Toward a science of transdisciplinary action research. American Journal of Community Psychology, 38(1), 63-77.

Swilling, M., \& Annecke, E. (2011). Just transitions: Explorations of sustainability in an unfair world. Cape Town: Juta and Tokyo: United Nations University Press.

Šapkova, A. (2014). System of mathematics teachers' beliefs about effective teaching/ learning and practice as a complex adaptive system. Journal of Studies in Education, $4(3), 15-31$.

Tainter, J. A. (2006). Social complexity and sustainability. Ecological complexity, 3(2), 91-103.

Tilbury, D. (2011). Higher education for sustainability: A global overview of commitment and progress. In GUNI (Ed.), Higher education in the world 4. Higher education's commitment to sustainability: From understanding to action (pp. 18-28). GUNI: Barcelona. 
Tillmanns, T., Holland, C., Lorenzi, F., \& McDonagh, P. (2014). Interplay of rhizome and education for sustainable development. Journal of Teacher Education for Sustainability, 16(2), 5-17.

Toomey, A. H., Markusson, N., Adams, E., \& Brockett, B. (2015). Inter- and transdisciplinary research: A critical perspective. Submitted to Global Sustainable Development Report Chapter 7 Policy Brief. Retrieved from: https://sustainabledevelopment. un.org/content/documents/612558-Inter-\%20and\%20Trans-disciplinary \% 20 Research\%20-\%20A\%20Critical\%20Perspective.pdf

UNESCO (2012). Guidelines for creating a National ESD Research Agenda and Plan. Education for Sustainable Development in Action Technical Paper No. 5 - 2012. Paris: UNESCO.

Valentinov, V. (2014). The complexity-sustainability trade-off in Niklas Luhmann's Social Systems Theory. Systems Research and Behavioral Science, 31, 14-22.

Von Bertalanffy, L. (1968). General System Theory. New York: George Braziller.

Wiek, A. (2007). Challenges of transdisciplinary research as interactive knowledge generation - Experiences from transdisciplinary case study research. GAIA: Ecological Perspectives for Science and Society, 16(1), 52-57.

Young, C. (2016). Assuming an epistemology of emergence: Classrooms as complex adaptive systems. In Ş. Erçetin (Ed.). Chaos, complexity, and leadership (pp. 131141). Cham, Switzerland: Springer International Publishing.

Young, K. (2000). What makes transdisciplinarity succeed or fail? Second report. In M. A. Somerville \& D. J. Rapport (Eds.), Transdisciplinarity: Recreating integrated knowledge. EOLSS Publishers Ltd; Oxford, UK.

Wells, J. (2013). Complexity and sustainability. Routledge.

Wiesmann, U., Hirsch Hadorm, G., Hoffman-Riem, J., Biber-Klemm, S., Grossenbacker, W., Joye, D., Pohl, C., \& Zemp, E. (2008). Enhancing transdisciplinary research: A synthesis in fifteen propositions. In G. Hirch Hadorn, H. Hoffman-Riem, S. BiberKlemm, W. Grossenbacker-Mansuy, D. Joye, C. Pohl, U. Wiesmann, \& E. Zemp (Eds.), Handbook of transdisciplinary research (pp. 433-441). Dordrecht: Springer.

Wilson, E. O. (1998). Consilience: The unity of knowledge. New York: Knopf.

Zheng, H. (2015). Teacher beliefs as a complex system: English language teachers in China (English Language Education, 4). Springer International Publishing.

Correspondence concerning this article should be addressed to Anita Pipere, Institute of Humanities and Social Sciences, Center of Sustainable Education at Daugavpils University, Vienības 13, Daugavpils, LV-5401, Email: anita.pipere@du.lv 